\title{
HASTA QUE LA MUERTE NOS SEPARE: UN ACERCAMIENTO AL SIGNIFICADO DEL VESTIDO DE NOVIA EN BOGOTÁ (1920-1930)
}

\author{
TILL DEATH DO US APART: AN \\ APPROACH TO THE MEANING OF \\ THE WEDDING DRESS IN BOGOTÁ \\ (1920-1930)
}

Por:

María Clara Salive Puyana ${ }^{1}$

Docente de la Universidad Central de Bogotá msalivep@ucentral.edu.co Colombia

Resumen: Vestirse e interactuar en distintos espacios genera instancias narrativas que reflejan la experiencia de habitar, a la vez que resignifican el sentido de los lugares. Cada práctica, como ir a cine, a cenar, realizar un deporte, asistir a una fiesta, discutir en un café o participar en un acto de caridad, supone una indumentaria en que pueden leerse signos de diferenciación social y roles de género, entre otros significados asociados a cómo se entienden los modos de verse y actuar según las ceremonias en que se participa. En el caso de las mujeres, cada uno de los vestidos que se asocian con su ciclo de vida, develan la concepción sobre su rol en la sociedad. Así, de 1920 a 1930, el matrimonio y la viudez, son vistos como parte de las representaciones de ser mujer, por las que transita este artículo.

Palabras clave: Vestido, mujer y ciudad. 


\begin{abstract}
Dressing and interact in different spaces generates narrative instances that reflect the experience of inhabiting, while redefining the sense of the places. Each practice like going to movies, dinner, do a sport, attending a party, discussing in a cafe or participate in an act of charity, is a garment that can show signs of social differentiation and gender roles, among other meanings associated with how the ways of being and acting are understood according to the ceremonies in which they participate . For women, each of the dresses that are associated with their life cycle, reveal the conception of their role in society. Thus, from 1920 to 1930, marriage and widowhood are seen as part of the representations of being a woman in which this article dwells.
\end{abstract}

Keywords: Dress, woman and city.

\title{
Introducción
}

"La incertidumbre de sí mismo genera en el ser humano la propensión a verse como otros y en imágenes"

(Belting, 2007, p.15).

Bajo el signo de lo nuevo, en medio de la aparente aleatoriedad del cambio y las lógicas prometedoras con que se avizora el futuro, la moda ha desplegado en el mundo moderno sus estrategias de seducción (Baudrillard, 1996), tras un discurso publicitario en que lo primero que se vende es la ruptura con la tradición. Sin embargo, paralelo a esas retóricas de imágenes y palabras que se construyen y retroalimentan con la complicidad de un sistema capitalista en el que el deseo de cambio siempre ha estado a la vanguardia, el vestido de novia ha mantenido significados que, dentro de períodos de larga duración (Bruadel, 2011)2, preservan su sentido, a pesar de los cambios en la forma que impone cada tendencia.

Si nos acercamos a la Bogotá de 1920 a 1930, encontramos que esta capital, como otras ciudades latinoamericanas, no fue ajena a los cambios vertiginosos que durante los años en cuestión acaecieron en la moda. La circulación en la prensa ilustrada influyó notablemente en las representaciones ${ }^{3}$ alrededor de cómo debía verse ese cuerpo moderno ${ }^{4}$ y la manera en que hombres y mujeres se percibieron a sí mismos (Traversa, 1997). Más aún, tratándose de una élite, cuya posibilidad de viajar, le permitió importar vestidos y asimilar diversos hábitos de consumo que comenzaron a transformar sus modos de sociabilidad. Departir en un café, asistir al club, realizar los denominados sports, o visitar los tea rooms, -tan significativos como un espacio ajeno a la casa para las mujeres-, son apenas algunos ejemplos de las transformaciones que, tras el letargo de la Guerra de los Mil Días, experimentaron hombres y mujeres de esta naciente burguesía.

Dentro de esta dialéctica entre lo que llegaba de fuera y lo que se creía adecuado según el orden de valores de los bogotanos y bogotanas de ese entonces, la indumentaria, sobre todo femenina, tuvo que negociar y adecuarse a esas ideas alrededor de ser hombre, mujer, niño o niña, que le son propias a cada cultura. Por ello, analizar los vestidos de novia implica detenerse en las diversas capas de sentido que se dan en estas imágenes, y las adaptaciones formales y de contenido que se hicieron de estas prendas, cuando incitaban a salirse de los códigos establecidos. 
Así, mediante un acercamiento a imágenes tomadas de las páginas sociales (Revista Cromos y El Gráfico), la publicidad y los álbumes familiares, con las fotografías de los corresponsales en el exterior, el fin de este artículo es acercarse al vestido que circuló en Bogotá y dilucidar desde ahí, ciertas narrativas alrededor del género, la clase social y las representaciones establecidas en ese momento (Jodelet, 1986), que se sumaron a la manera creativa en que una burguesía feudal ${ }^{5}$ saltó a la escena con su particular idea de lo que consideró preparar su cuerpo y sus vestidos para ser modernos y habitar en la ciudad.

Abordar las imágenes que se construyeron mediante el vestido, implica detenerse no en los significados de las imágenes que pudieron hacerse legibles en cualquier tipo de texto, sino procurar "tomar como tema el significado que las imágenes recibían y tenían en una sociedad en particular" (Belting, 2007, p.19). Así, en medio de ese discurso que inevitablemente se instaura cuando se porta una prenda, entran a dialogar esas formas que son importadas de Europa y Estados Unidos, con las necesidades expresivas de los bogotanos y bogotanas de la época. Siguiendo a Foucault (1978), cada grupo instituye unos órdenes discusivos para regular sus instituciones y el vestido no podía quedarse al margen de estos lineamientos.

Tras este proceso de mediación y adecuación de las imágenes que circularon en la ciudad, el discurso de la modernidad jalonaba al cambio, pero no sin objetar aquello que pudiera romper con lo que se creía conveniente. Una idea de "ser modernos" que, vale aclarar, en la retórica de las revistas de ese entonces se usó indistintamente como un adjetivo que en cuestiones de estilo y de consumo, exaltaba lo que se consideraba novedoso y, por lo tanto, augurio de progreso y de bienestar. Muletilla que junto a la palabra moda, hizo parte de ese tinte aurático (Benjamin, 2012) con el que, tras la Revolución Industrial, se recubrían las mercancías.

Para figurar dentro de las esferas de la distinción y marcar la distancia con los "ruanetas", se monopolizaron ciertos bienes de consumo que alejaban a esta naciente burguesía del estigma de atraso que llegaron a representar objetos como la mantilla y el faldón colonial. Lo anterior, no excluía que se mantuvieran latentes en cada cambio que se aceptaba, modos civiles y concepciones del cuerpo, donde tuvieron que convivir las ideas que se creían modernas con los remanentes de lo señorial: "Sentirse y lucir como una ciudad culta fue un propósito explícito de la Bogotá republicana que quiso prolongar su tradición de Atenas Suramericana. Hacer ostentación de buenos modales significaba exponer en la forma de una tradición de costumbres refinadas, un patrimonio que era equiparado con cultura" (Pedraza, 1999, p. 12). Dicotomía de la que el vestido de novia no podía mantenerse al margen.

El vestido hace parte de la cultura y esta es una colcha de retazos que adapta creativamente ideas prestadas y referentes disímiles, bajo el llamado del cambio y la lógica que tras ésta agencia la moda como su más cercano correlato (Baudrillard, 2002). Cortarse el pelo, encasquetarse un sombrero acampanado o aceptar quitarse 
el corsé, hizo parte de los discursos alrededor del cuerpo, la higiene, el habla culta y la urbanidad. Se asociaron de manera contundente con un vestuario que reforzó mitos alrededor de las aspiraciones y abolengos de aquellos ciudadanos (y aún no ciudadanas) que buscaban "el progreso", antes que la vulgarización y la democratización de ciertos modos civiles amenazaran el repertorio sobre el que construyeron gran parte de su identidad los cachacos y las damas santafereñas. Los dos tan bien vestidos, poetas y políglotas, en sus fiestas y tertulias quedaron plasmadas muchas de las narrativas ${ }^{6}$ alrededor de alcanzar esa idea de ser modernos, atravesada por los matices y traducciones con que se acomoda este concepto a las conveniencias y preferencias de dicha élite ilustrada y su afán por demostrar que eran los portadores de una cultura más aventajada. Al respecto dice Madam Valmore: "en esta época en que tantas ideas nuevas fructifican en el campo de las reformas sociales, en que tantas semillas renovadoras nos preocupan, las modas adquieren día a día mayor importancia estética y social" (Cromos 1922, febrero 11, p. 293).

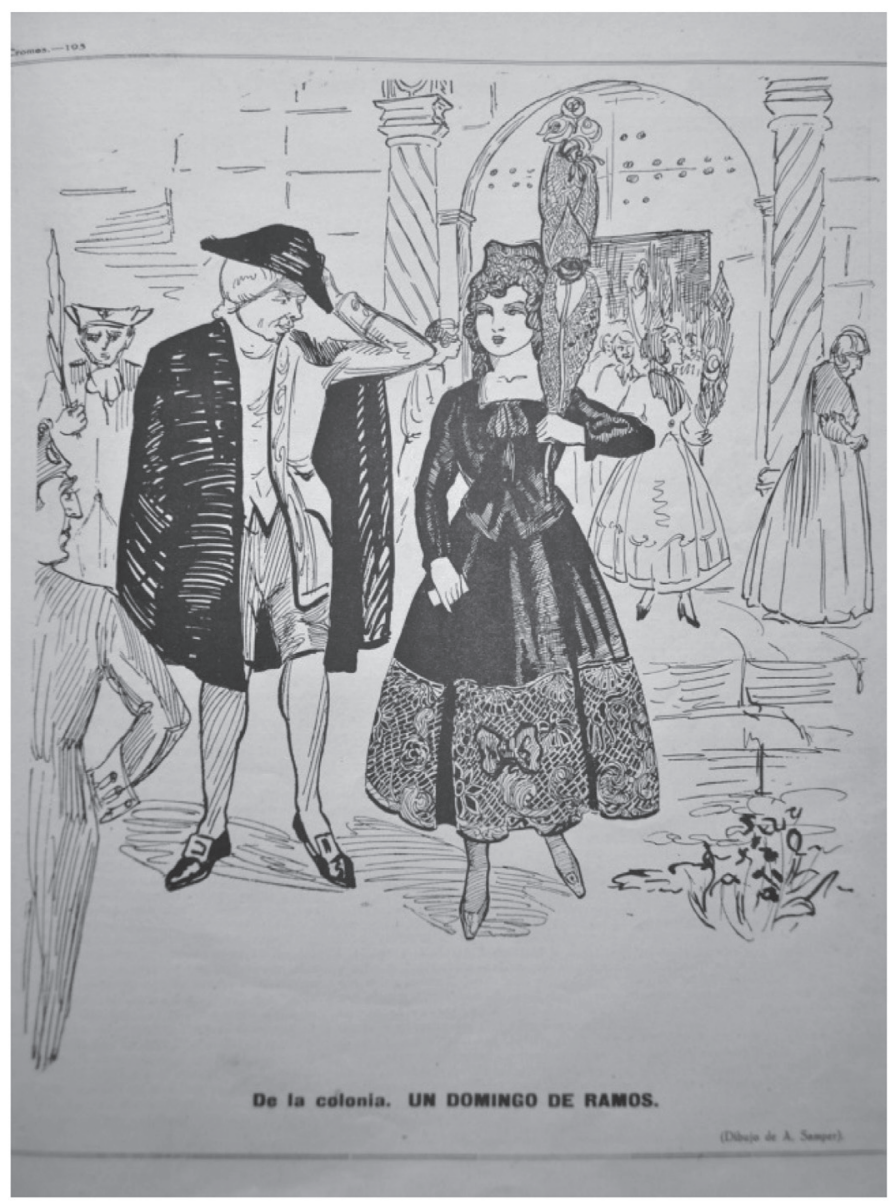

Figura 1. Un nostálgico artículo da cuenta de la mantilla bogotana como un remanente de lo señorial en la mentalidad de los bogotanos de esta época. (Cromos 1922, abril 1, No. 300). 


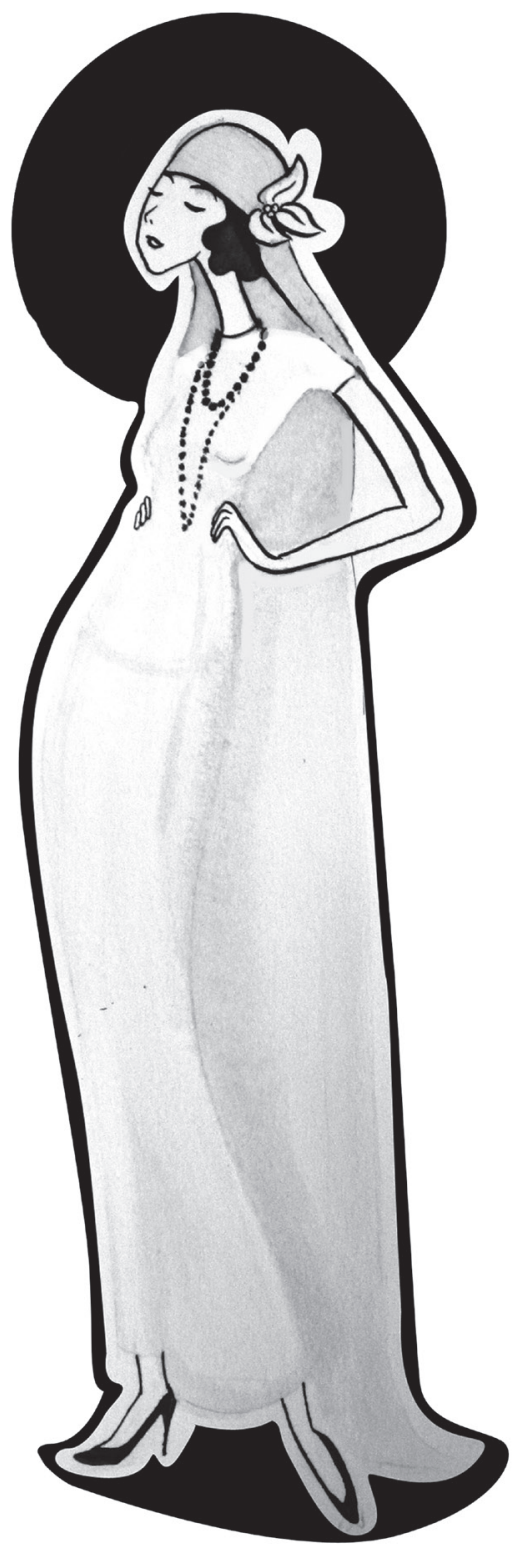

Capital cultural (Bourdieu, 1994) que no sólo se exhibía en las interminables alusiones grecolatinas, en la exorbitante profusión de anglicismos, galicismos y palabras en otros idiomas (incluso en el periodismo que se consideró moderno), sino que permeó el discurso ilustrado como un bien que, junto al vestido, era esencial para ser aceptados en las altas esferas de la sociedad. Ya desde 1900 Clímaco Soto Borda (1956), aludía a esta obsesión de la hight class capitalina por los productos extranjeros y por exhibir, a través de la ropa y la palabra su estadía en el exterior.

De esta petulancia se burla con cinismo el autor: "No llamaban a los chicharrones cuir de porc ressuré, ni la chicha liqueur jaune, ni la mazamorra puré gris, ni al tiple petit contre-basse, ni el torbellino la danse du ventre." (Soto- Borda, 1956, p. 6). Cómo sería esa obsesión de las élites por asociar lo venido de fuera con ensoñaciones de progreso y estatus, que hasta la epidemia de gripa que con tanto dramatismo describe José Antonio Lizarazo en su crónica, fue acogida con cierto orgullo, ya que no fue un brote local, sino una pandemia universal (Londoño y Londoño, 1989).

Ahora bien, tras esta breve introducción por la idea de ser modernos que circuló en Bogotá y sus contradicciones, se pasará a analizar la relación entre el vestido de novia y esas creencias asociadas a la moda que mantuvieron en su esencia estructuras sociales arraigadas a imaginarios de clase y género, provenientes de una estructura social basada en un remanente feudal que comenzó a mezclarse con un estilo de vida burguesa, propio de lo que se consideró ser modernos y habitar en la ciudad.

\section{Objetos de culto, sujetos del deseo}

No olvides nunca que el primer beso no se da con la boca, sino con los ojos.

O. K. Bernhardt

Analizar el vestido de novia implica detenerse en el significado del matrimonio y entender que esta alianza atávica se desprende de la necesidad de establecer instituciones, roles y hábitos en cada grupo humano (Berger y Luckmann, 1968). Así, mientras el hombre iba de caza, la mujer cuidaba el fuego, rol que se va transformando en la medida que cambian las circunstancias económicas, culturales y sociales propias de cada grupo humano. Dejando por ahora a un lado el significado que el catolicismo le ha otorgado al matrimonio, en cada alianza entran en juego intercambios comerciales que atañen al territorio. Entender estas alianzas entre el vientre que carga al primogénito y la tenencia de la tierra, hacen de este ritual social, un medio tras el cual se garantiza la estabilidad de la comunidad, el poder y la circulación de bienes. 
Es aquí donde se instituye el símbolo y la importancia atribuida a los trajes de los novios y a todos los elementos que acompañan la unión: en cada ritual (De Certeau, 2000) se escenifican los valores de la comunidad que pone en juego sus creencias en la fiesta o en la ceremonia religiosa en que se comparte el triunfo de una buena alianza. Antes de dar el sí, el proceso de cortejar a la novia, sin mancillar su honor, es todo un ritual, cuyo escenario es el balcón. Aquella prolongación de la casa que, desde la Colonia, protegía a las jovencitas santafereñas de mezclarse con el peligroso mundo masculino. De esta parte de la casa, que tan sutilmente conecta lo público con lo privado, se dice con nostalgia: "Malos estaban todas las tardes en el balcón; eran unas santafereñas de lo fatuto; que se sentaban a ver pasar la gente: se ponían unos trajes vistosos y usaban unos gruesos collares de esmeraldas; también salía una negra con brasero; la bandeja de los mantecados, las jícaras de plata; y las viejas, mirando pasar la gente tomaban ahí su chocolate" ( Revista Cromos 1921, octubre 29).

Modernos podían ser los vestidos y ya en ese entonces los hombres en el café, bebían este trago amargo. No obstante, a la hora de cortejar a una novia, la caballerosidad de espada al cinto, seguía siendo un símbolo de ensoñación romántica como la describía el Doctor Mirabel, a propósito del uso de la barba y la galantería: "Ese galante quiere decir que eran además valerosos y entusiastas; que eran capaces de hacer trepar su caballo a un balcón por alcanzar una sonrisa” (Revista Cromos, 1922, marzo 25).

Si el caballero era aprobado por la familia, según los intereses de las clases altas de mantener el monopolio del poder económico y social, al novio se le permitía seguir a la sala, obviamente bajo la vigilancia estricta de un hermano mayor o los padres. Del intercambio de chocolates, postales y poemas, dan cuenta la publicidad de ese entonces (Figura 2): toda una iconografía reforzada por las películas y las prohibidas novelas de Vargas Vila o la menos censurada María de Jorge Isaacs. Poco valía suspirar por el hombre o la mujer amada, si la obligación de casarse con quien se consideraba más conveniente, según la familia, seguía siendo un remanente de la mentalidad feudal, aún alejada de esa idea moderna de la que habla Marshall Berman en que las elecciones hacen parte de las nuevas experiencias que se le abren al individuo del siglo XX: "ser modernos es encontrarnos en un entorno que nos promete aventuras, poder alegría, crecimiento, transformación de nosotros y del mundo, y que, al mismo tiempo, amenaza con destruir todo lo que tenemos" (1991, p. 1).

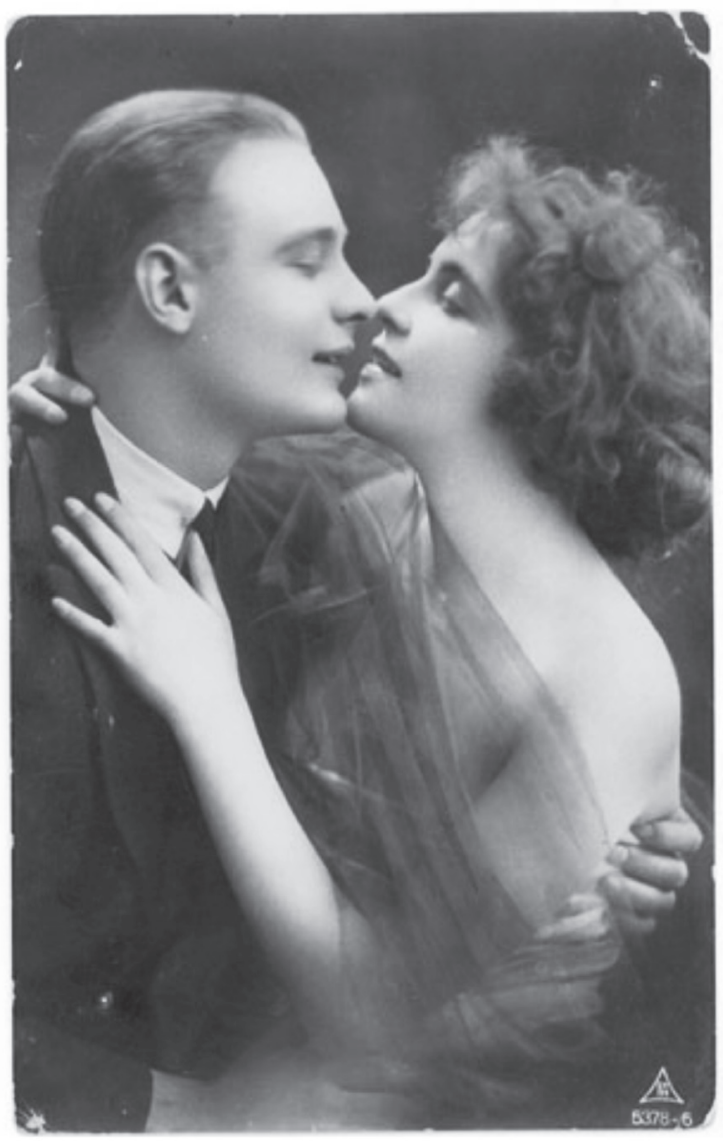

Figura 2. Esta postal romántica de 1926 que aparece titulada como La Fiesta, es una muestra de la iconografía que circulaba alrededor del amor idealizado, propio de las películas y novelas de ese entonces. (Álbum Familiar de Bogotá, 2013). 
Tras una que otra serenata, la bendición de los anillos que se denominaba la "argollada" (Londoño y Londoño,1989) y las vistas de rigor a los familiares más cercanos, se oficializaba la unión en público, y para que no hubiera posibilidad de arrepentirse, so pena al escándalo y la deshonra de las familias, quedaba constancia en las revistas: "invitados al compromiso matrimonial del notable pianista, don Armando Palacios con la señorita Cecilia Pérez Currea, ceremonia verificada en la legación de Chile" (Revista Cromos, 1929).

La argolla entregada antes de la unión, no sólo es un círculo que sella la alianza, también es una piedra preciosa que da cuenta de la capacidad económica del novio. Más adelante, los dos portan este círculo asociado con la eternidad, buscando con ello garantizar que la alianza bendecida ante los ojos de Dios, no se rompa, y con ello se vea establecida una familia segura y dispuesta a repetir el ritual descrito, con la certeza de que el matrimonio también estabiliza órdenes sociales más allá de la intimidad.

Cuando llegaba la tan esperada fecha, los matrimonios se celebraban casi al final de la mañana, y la fiesta se realizaba en los grandes salones de las casas de ese entonces, o en los clubes sociales. No eran pocos los chismosos que acudían al púlpito, además de los invitados que, según su prestancia y cercanía con la familia, ocupaban los primeros puestos en la iglesia. La novia entraba de blanco y tras este impoluto color, connotaba su virginidad, garantizando con ello que ese hijo primero fuera sólo de la familia que la entregaba en el ritual matrimonial. El novio, como aún lo dictaba el ritual católico, debía llegar primero y esperar en la iglesia, mientras el padre se libraba de la responsabilidad de su hija, delegando ese deber a quien sería su esposo.

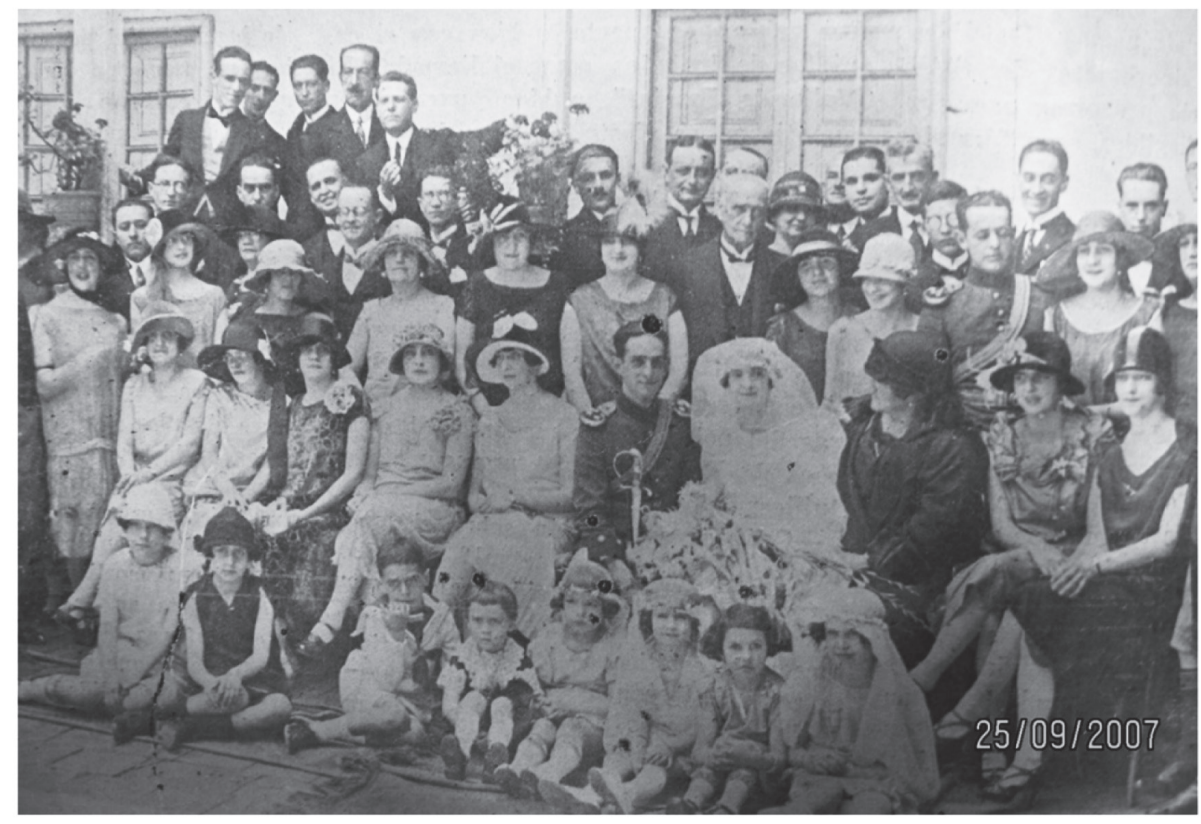

Figura 3. Fotografía de la celebración de un matrimonio en la que se puede apreciar, el vestuario de la época. En estas ceremonias se hace pública la consolidación en el ámbito privado de la unión familiar. Revista Cromos, 1928. 
Son muchos los detalles y los símbolos que alrededor del matrimonio católico se asocian con el vestido: ese objeto tabú (Freud, 1974) no puede ser visto por el novio antes de la ceremonia. Anteceder el deseo que inspira la novia, puede romper el equilibrio precario de esa pureza que debe ser entregada en el momento oportuno, para no alterar la mágica percepción que se tiene de los órdenes establecidos en cada ritual, y que suponen una delicada sintaxis donde el antes y el después armonizan la estructura inherente a cualquier acto ceremonial.

A su vez, el vestido es un adentro y un afuera (Saltzman, 2007) que como cuerpo, piel y presentación frente a los otros, sintetiza su finalidad. A la vista, metros de encajes, sedas o tules, estarán expuestos frente a los ojos de ese público que testimonia el sí de los implicados que se dirigen al altar. Adentro la ropa interior: esa que por primera vez verá el otro y que tímidamente será removida en la noche de bodas. Era mucho el silencio que se debía guardar alrededor de la consumación de la unión, aunque en los círculos de las personas ilustradas, ya circulaban muchos anuncios sobre baños íntimos, entre otros cambios en la concepción del cuerpo que comenzaban a romper ciertos tabús sobre los pecados de la carne, tan arraigados en la iglesia católica. Aunque ya se publicitan medias de seda, fajas más cómodas que el corsé, entre otros aditamentos que por la transformación del vestido liberaron un poco el cuerpo de la mujer, los anuncios son ilustraciones, pues mostrar las piernas o exhibirse en vestido de baño, como ya lo hacían en Europa y en Estados Unidos, continuaba generando fuertes controversias entre las ideas de fuera y la moral imperante. Dicotomía con la que negoció el vestido de novia, cuyas transformaciones formales, no supusieron mayores cambios en los idearios alrededor de los roles establecidos entre hombres y mujeres.

La mancha sagrada que en ciertos grupos de católicos era expuesta al público, aunque quedara sólo en el lecho nupcial, seguía siendo un símbolo de que el ritual se completaba de manera satisfactoria. Era mucha la fe que se le tenía a este feliz comienzo: cada cosa que pudiera fallar era un augurio terrible.

Figura 4. Fotografía en que se puede apreciar el vestido de novia que se popularizó durante la década del treinta. En este período se hace notorio que el vestido retoma el largo que se usó en el XIX, sin el ancho del traje polisón. Transformaciones formales que no compiten con la simbología mariana del traje de novia (Revista Cromos 1935, enero 19).

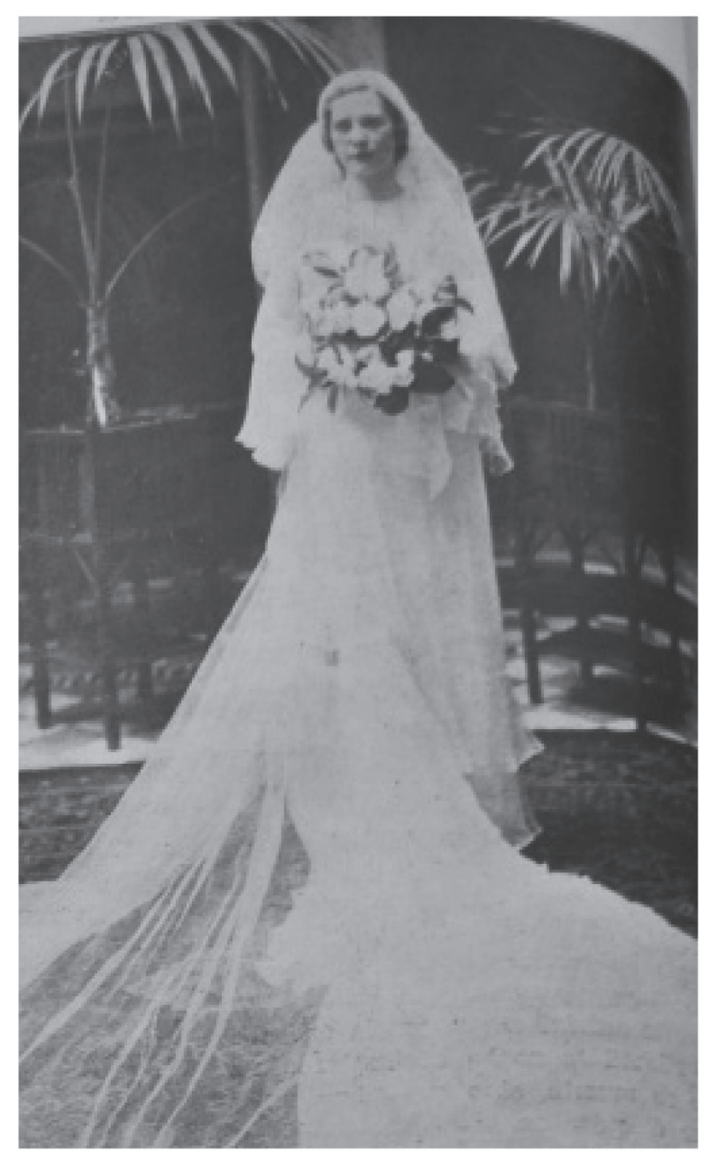


El ramo siempre ha sido visto como parte de la bendición que dará suerte a las solteras, quienes necesitan que el matrimonio las lleve a sumarse al seguro mundo de las parejas casadas. Quedarse para vestir santos, era una de las más terribles desgracias, en una época que casi no daba opción a otro proyecto de vida para las mujeres. Esto, sin olvidar llevar algo nuevo, algo usado, algo propio, algo regalado y algo amarillo. Representaciones del porvenir, el pasado y los buenos augurios. El amarillo, como en el año nuevo, simbolizaba ese color áureo asociado al poder, el dinero y la energía solar (Cirlot, 2006). En ambos casos se celebraba el inicio de un ciclo y elegir este color presuponía la buena suerte con que se asocian los significados que aquí se enumeran someramente.

Según la tradición inglesa, utilizar el rojo en este tipo de ceremonias, connotaba una virtud dudosa y, por lo tanto, aún se considera que no es un color adecuado para una novia, mientras el amarillo, aunque ha sido poco común, es asociado a la diosa griega del matrimonio y la fertilidad, Himen. El amarillo tradicionalmente ha tenido que convivir con la idea de ser un color que trasmite envidias y promueve los celos, por lo que se usa discretamente como parte de los objetos fetiche que se llevan sobre el cuerpo (Cirlot, 2006). Las perlas, tan de moda en los años veinte, podían traer la muerte y la viudez, por lo que en algunas culturas también se relacionan con mala suerte.

Como se puede apreciar, el vestido, como un universo sígnico, es un discurso en el que habita el cuerpo, y ante el orden que desde las instituciones se le imprime a las palabras (Foucault, 2005), en cada indumentaria, se transluce la forma en que se quiere ser mirado. El poder de la ropa va más allá del signo mismo; es imposible no interpretar el vestido del otro y más difícil aún, no decir nada con lo que se lleva puesto. No hay un grado 0 del vestido, como lo insinúa Barthes (1972) para la escritura, tampoco hay ese grado en la interpretación. Si se piensa que no se quiere decir nada con lo que se lleva puesto: un pantalón negro y una camisa del mismo color o el icónico vestido negro de Coco Chanel (imagen 3): ¿Cuántas cosas se dicen con eso? Es sencillo comprender que cualquier pausa discursiva dice más que mil palabras. Baudrillard, cuando en su famosa Crítica a la economía política del signo (1984) afirma que el valor de uso es un mito dentro de la sociedad capitalista en Occidente, se refiere a todos los objetos, pero el vestido sí que corrobora esta hipótesis.

Volviendo al universo de los signos que tanto le atañen a los vestidos, el negro que se asocia a la viudez, expresa un estado de ánimo opuesto al color blanco, signo de comienzo y pureza en la cultura occidental. La mantilla negra, acompañaba el luto riguroso que se esperaba en ese entonces que se prolongara por los menos 6 meses, privaba por largo tiempo a las mujeres de exhibirse con otro tipo de indumentaria (Figura 2), sin omitir que para ir a misa este accesorio era imprescindible. Una vez se consideraba que el principal fin de las mujeres era honrar al marido y cuidar a su descendencia, la viudez sumía a las esposas en una muerte en vida. La tristeza debía hacerse pública, y además del negro riguroso, la ausencia de joyas y las mínimas apariciones en público, enfatizaban el amor y el respeto al difunto. También se usaba que el pelo se mantuviera recogido y se asistía 
a misa con sayón negro de paño grueso. Las ventanas de las casas debían permanecer cerradas, los espejos cubiertos y dependiendo de la edad, las hijas irían aumentado el uso de otros colores gradualmente, mientras su madre, dependiendo de su edad, podía prolongar el luto por muchos años más, e incluso hasta la propia muerte.

Mientras en ciertas épocas y contextos el negro connota respeto y tristeza, cabe anotar que para muchos, desde los años veinte, hasta hoy, es sinónimo de elegancia y sobriedad. Más aún tras el icónico vestido negro de Coco Chanel, quien en la Revista Vogue de Octubre de 1926, instaura este estilo sobrio y muy acorde con la guerra, pero que más adelante será el tan anhelado grado cero, que le permite a las mujeres estar bien presentadas en cualquier contexto.

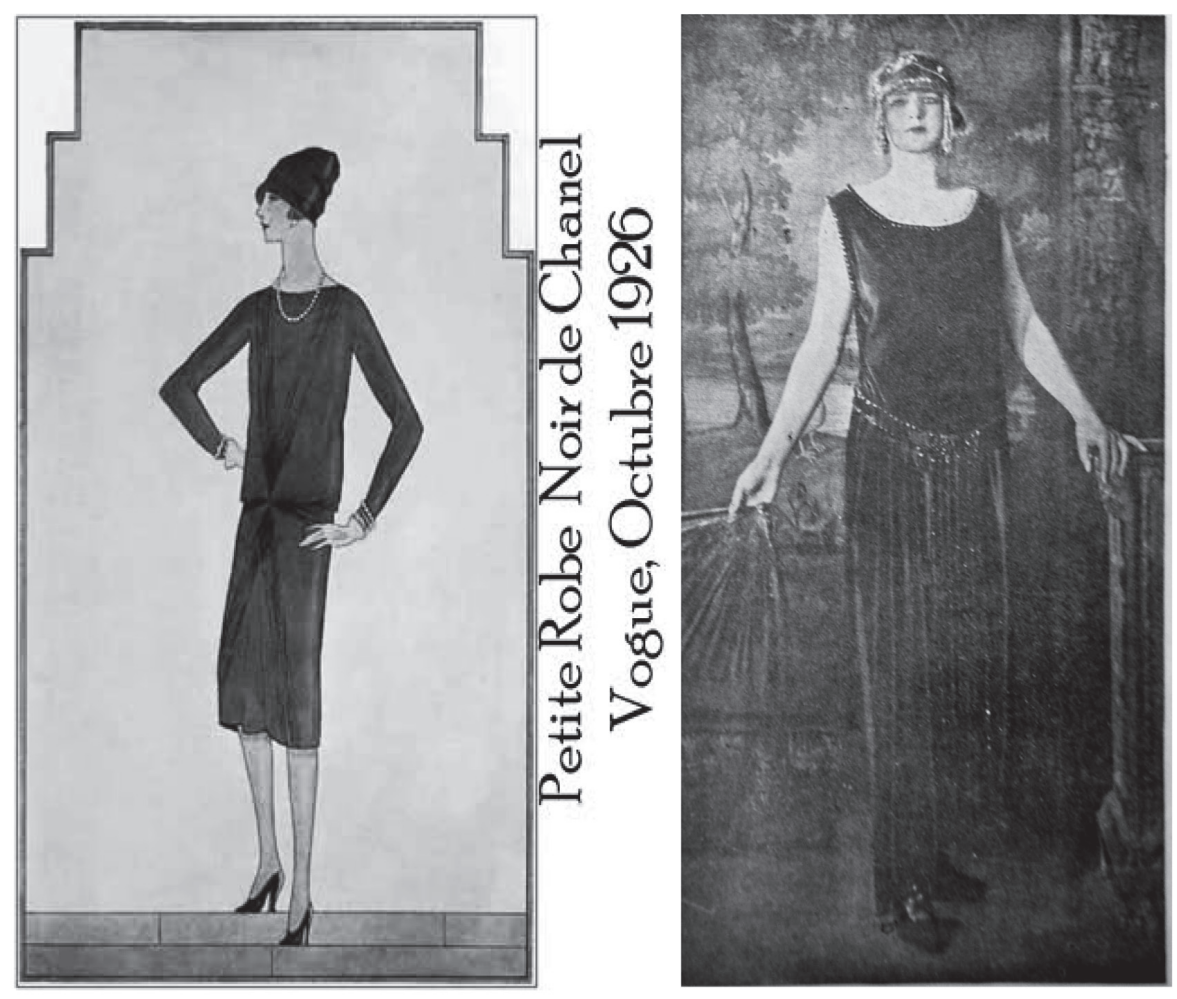

Figura 5. Ejemplos de los icónicos vestidos negros que circularon durante la época. Cromos 1922, febrero 11. 


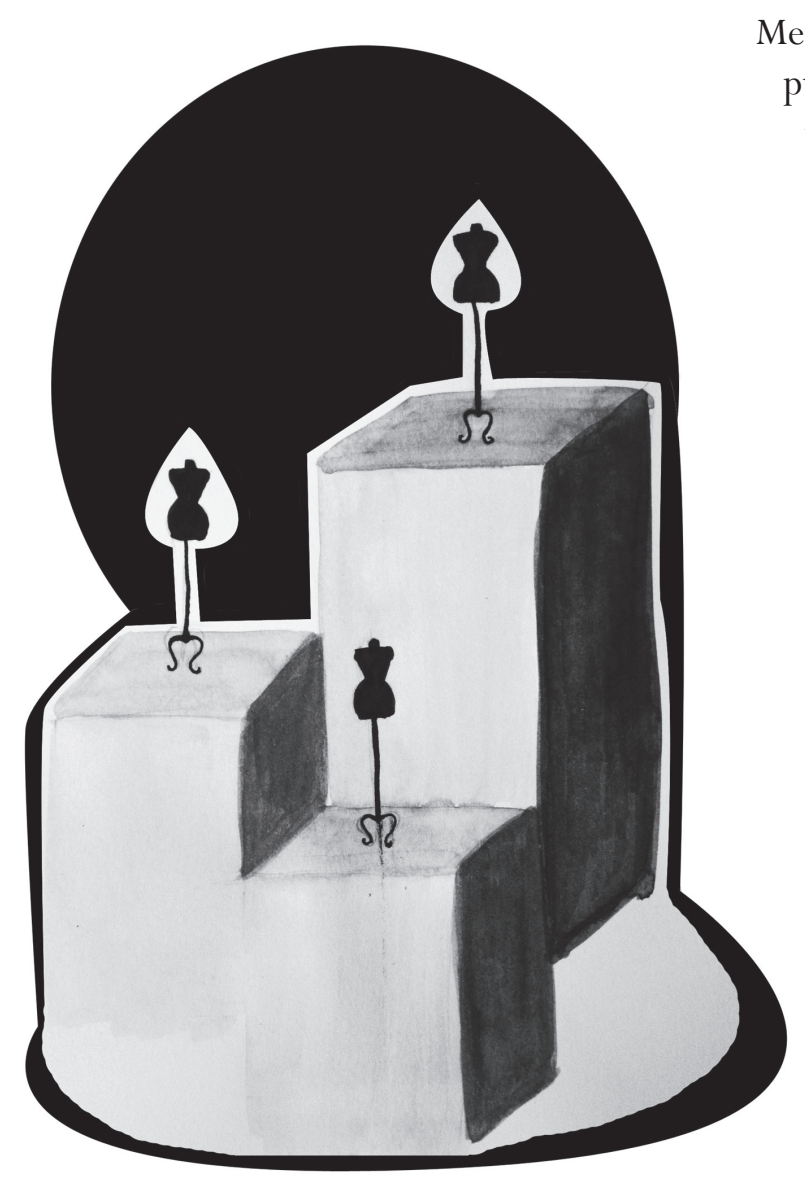

Mediante los ejemplos del vestido de novia y el de la viudez, se puede ver la forma en que cada ritual de interacción instaura unos órdenes discursivos (Foucault, 2005, p.12) alrededor del poder, la verdad, los supuestos alrededor de lo apropiado, lo inadecuado y el código. Hombres y mujeres se visten guiados por el deseo, pero se desea ser aceptado por los otros, lo que implica una construcción del yo donde media el código impuesto por la cultura. Es ahí donde el diseño intenta traducir esos deseos tan disímiles y contradictorios como el sentido que se le da a los objetos y los impulsos que guían las decisiones de compra. Un vínculo emocional que lleva a las personas a escoger un color, una textura o un estampado, sin con ello atreverse a romper del todo con los significados establecidos por sus semejantes, los cuales se mantienen en diálogo constante con las imposiciones de la moda y su uso social.

\section{Vestidas de novia en los años veinte}

Ahora bien, ¿qué caracterizó el vestido de novia de los años veinte en Bogotá?, ¿cómo se mezcló la tradición con el culto a la novedad en ese repertorio de telas y encajes con que se vivió ese ser modernos que la burguesía feudal construyó en sus ceremonias? Interrogantes que nos llevan a pensar en la tradición y el culto a la novedad que aún hoy se cuelan en los atuendos de las novias. El manto blanco que recubre a la novia, reproduce la identificación de las mujeres con la Virgen María; ideología mariana, que se proyecta en la envestidura, escindiendo tajantemente la corporeidad femenina con lo asexuado y el servicio a Dios (Puyana, 1997).

$\mathrm{Al}$ acercarnos a los años 20 tendríamos que comenzar por señalar que ese vestido que sube hasta el tobillo y ese sombrero encasquetado hasta casi las pestañas, no fue ajeno a los trajes de novia que lucieron con orgullo las mujeres de la época. En el repertorio iconográfico de ese entonces se puede observar cómo el novio utilizaba el sombrero de copa, la levita victoriana, el chaleco y la línea del sastre en el pantalón, mientras su novia lucía el pelo más corto, y en vez de sombrero, el velo simulaba la forma acampada de este famoso accesorio que recubrió la cabeza de las mujeres de los años veinte. La modernidad en ese estilo marcado por la Primera Guerra Mundial, aquí aparece reflejada en menos metros de tela. Las novias modernas ya no optaban por el vestido polisón y, en vez de ese corte victoriano que precedió el fin del corsé y el miriñaque, buscaron la ligereza impuesta por Chanel. 

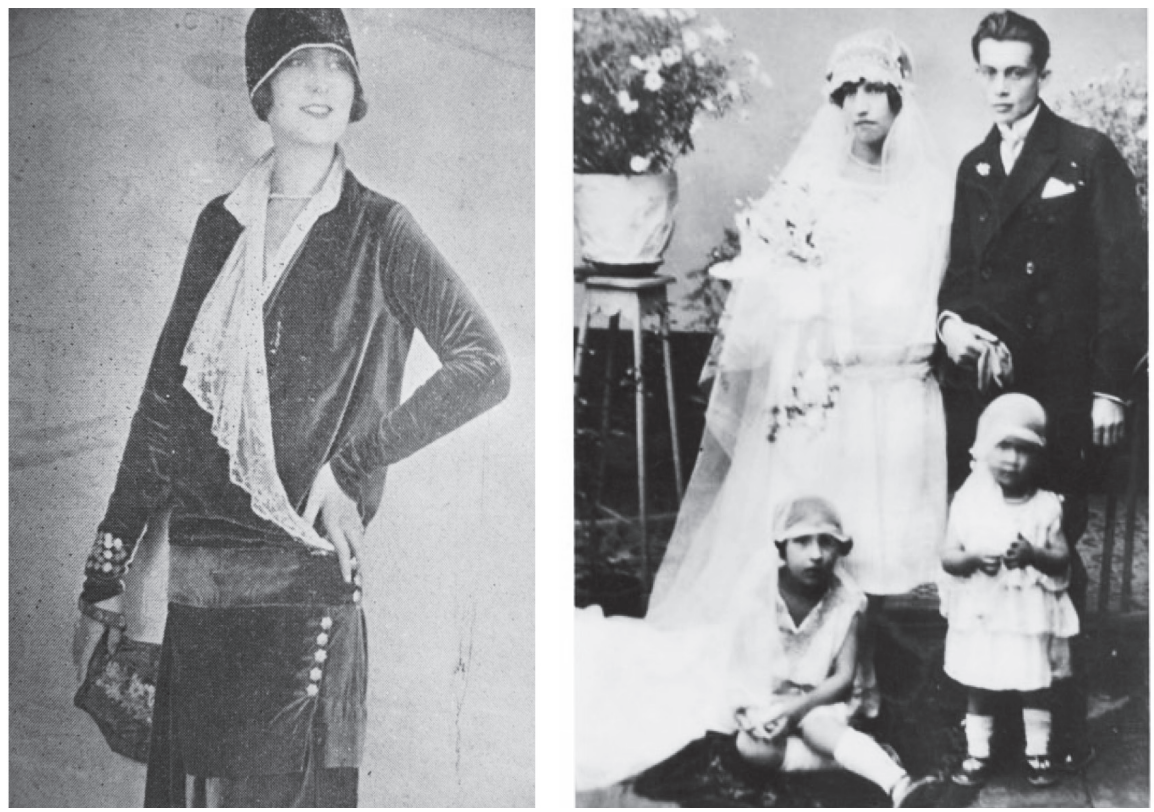

Figura 6. Cromos 1928 (Izq), Matrimonio González 1927 (Der) (Álbum Familiar de Bogotá, 2013). En estas fotografías se pueden comparar las similitudes en el vestido de los años veinte, y los que escogen las novias para no desentonar con la moda del momento.

No obstante, ese vestido de encaje con menos metros de sedas y tules, no dejó de marcar que estar de moda era cuestión de estatus. Así, a las formas cambiantes de la moda, que exhiben lo efímero como su bandera, el significado latente poco cambia: el blanco sigue siendo blanco y aquellas que ese día escogen un atuendo oscuro, son en su mayoría, porque recientemente han perdido a un ser querido o son viudas. Ceremonia en que la fiesta respeta el duelo y se equilibra el culto por los difuntos con el ciclo de renovación implícito en el matrimonio.

Lo atávico y lo nuevo convergen en esta sociedad que se ve abocada a "borrar el pasado colonial; con miras a instaurar una nueva forma de vivir. Al producto de esa transformación, pero también a la época en que tomó forma y se produjo como realidad, Romero la denominó “ciudad burguesa” (Mejía Pavony, 1999). Las instituciones propias de la burguesía, continúan ceñidas a la tradición familiar, a la vez que caprichosamente cedían a los signos del cambio que dictaba la moda, perpetuando su pasión por demostrar que se tenía dinero; más tratándose de esa burguesía feudal descrita por Santiago Castro (2011) en Tejidos Oníricos, la cual en los años veinte vivía de la tenencia de la tierra, pero los ritmos de la urbe ya la habían obligado a cambiar muchos de sus modos civiles. Dentro de estos cambios formales en el vestido, el significado del ritual matrimonial no tuvo transformaciones significativas de fondo, aunque los vestidos y la introducción de ciertos bailes como el fox trot y el charleston, mezclado con los bailes colombianos que ya desde 1910 comenzaban a disfrutar las élites en otras celebraciones, ya le estuvieran dando a la ciudad ciertos visos cosmopolitas (Londoño y Londoño, 1989). 
La clase alta impuso un estilo de vida en el que gozar del dinero y exhibirlo como capital simbólico, social y cultural (Bourdieu, 1994) hizo parte de esas relaciones sociales que se hicieron más fluidas en los sectores pudientes, como parte de esos bienes que les permitieron participar de la vida de la ciudad y dar cuenta de su poder frente a los menos adinerados en festividades como los matrimonios.

Por otro lado, la prensa escrita, que desde el siglo XVIII fue una herramienta para expresar públicamente el pensamiento individual, permeó, mediante esos "cuerpos de papel” (Traversa, 1997) los idearios de muchas personas. En las páginas sociales de la Revista Cromos, El Gráfico Ilustrado, el periódico El Tiempo, entre otros, se encontraban a la orden del día los matrimonios de los individuos más influyentes de la sociedad. Esto, sin que también se exhibieran fotografías y poemas de las casamenteras, a la vez que cuando un rico graduado volvía de hacer estudios en el exterior, su fotografía y su resumen profesional, lo hacían candidato para uniones convenientes entre las élites capitalinas.

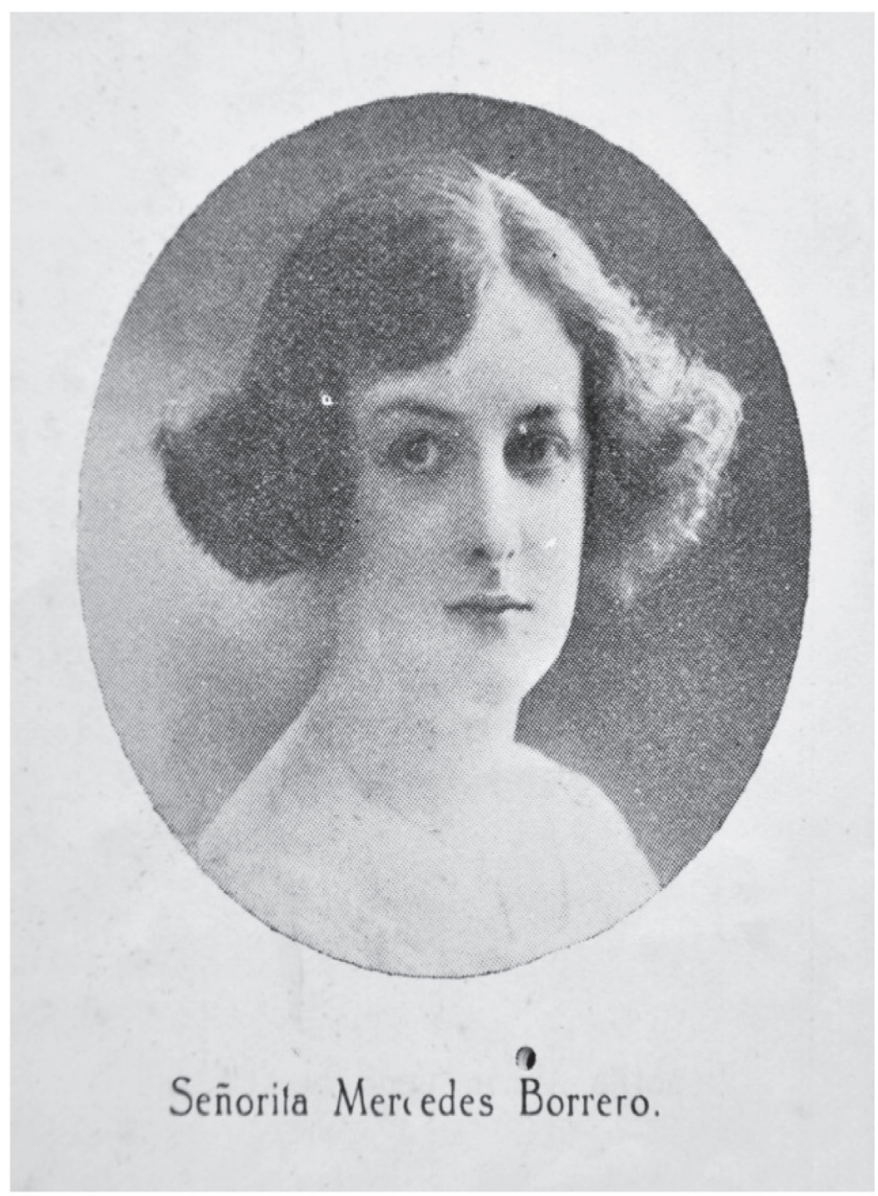

Figura 7. Fotografía que ilustra la manera en que las casamenteras de ese entonces publicitaban su imagen en la revistas. (Cromos, 1923, 383). 
En síntesis, el matrimonio, los símbolos que lo rodean y lo rodearon, demuestran que este ritual y sus vestidos reflejan las creencias de cada cultura, a la vez que se prefiguran los cambios sociales y culturales que lo acompañan. Son más leves los cambios que las permanencias, en la medida que las alianzas matrimoniales llevan consigo un orden, cuya práctica representa todo ese discurso sobre el que se cimienta la vida social. El mismo significado sobre el amor, la vida en pareja, se escenifica en los símbolos que acompañan cada ritual. Ir al altar para iniciar una vida en pareja, hace parte de la manera en que los individuos organizan sus órdenes institucionales y emocionales, a la vez que escenifican la época en que viven. El vestido, imagen, cuerpo y discurso, enuncia y es parte fundamental en cada ritual de interacción y sus lógicas enunciativas.

Del bautismo hasta la muerte, se habitan vestidos para festejar, para trabajar y para iniciar la vida en pareja. Prácticas cotidianas, donde lo sacro y lo profano, lo público y lo privado determinan el paso de hombres y mujeres, y su estar en el mundo. Como indicador cultural y para la historia del diseño, es determinante detenerse en qué dicen los objetos, en este caso el vestido, como un signo que enriquece la comprensión de la cultura material de los colombianos y colombianas. Este es solo un ejemplo de lo mucho que queda por decir al respecto.

\section{Notas}

${ }^{1}$ María Clara Salive Puyana es Profesional en estudios literarios de la Pontificia Universidad Javeriana de Bogotá y Maestra en Historia y Teoría del Arte y la Arquitectura de la Universidad Nacional de Colombia. Candidata a Doctora en Estética y Crítica, Arte y Arquitectura en la Universidad Nacional de Colombia. En su trayectoria como investigadora ha trabajado el tema de literatura y ciudad, en la tesis de maestría sobre El Carnero de Juan Rodríguez Freile - Bogotá 1538-1638-. En la actualidad, se encuentra estudiando las dinámicas de consumo, en especial el vestuario, en la Bogotá de 1920 hasta 1940. Se desempeña como docente de Publicidad y Consumo en la Universidad Central (Bogotá). Contacto: mcsalivep@gmail.com, msalivep@ucentral.edu.co

${ }^{2}$ Braudel, clasifica el tiempo histórico en tres tipos de duración social: larga duración, coyuntura y acontecimiento o corta duración. La larga duración es una historia secular que se sitúa por encima lo inmediato o coyuntural. La larga duración cambia lentamente y tiene, por consiguiente, una estabilidad grande en el tiempo que puede abarcar varios siglos y resulta muy útil para la reflexión en las ciencias sociales.

${ }^{3}$ El concepto de representaciones que se utiliza a lo largo de este texto, alude a la manera en que ciertas ideas, creencias y valores que comparte una colectividad, pueden llegar a hacerse visibles en imágenes u objetivarse en ciertas prácticas. (Jodelet,1986 )

${ }^{4}$ El presente artículo parte de la palabra moderno, como ese adjetivo que circuló en las revistas de ese entonces, muchas veces más cercano a la idea de modernización que a la de modernidad y, otras, con disímiles connotaciones. Esta última alude a transformaciones más profundas en los individuos en su mentalidad, valores, actitudes y acciones, las cuales se dieron de manera diferente en cada contexto, pero sin importar la clase social. Por ello, muchos afirman que en Colombia hubo modernización; proceso socio-económico de industrialización y tecnificación, sin modernidad. Postura que se complementará, más adelante, al introducir el concepto de modernidad cultural. En (Berman, 1991) (Viviescas Fernando comp, 1998). 
${ }^{5}$ A pesar de que en Colombia, en los primeros años del siglo XX, mucha de su economía aún se sustenta en la hacienda, ciertos procesos de industrialización comenzaron a incidir en las relaciones sociales de los habitantes de la ciudad. Esta mezcla entre las rentas que vienen del campo, las nuevas formas de socialización que se generan en los núcleos urbanos y los cambios en los hábitos de consumo propios del capitalismo, dan cabida a lo que Castro- Gómez denomina burguesía feudal (CastroGómez, 2009)

${ }^{6}$ Dentro de las muchas acepciones que tiene el concepto de narrativa aquí lo abordo como algo que le sirve a los individuos para ordenar y proveer de significado la realidad que los circunda. Es una manera de conferir sentido y finalidad a la experiencia. Desde la semiótica es la comprensión de la sucesión de estados y cambios, mediante los cuales se cuenta algo. Esta enfoca las relaciones actanciales que se encuentran insertas en los relatos. Tras estos esquemas verbales y no verbales, se asocian ciertas figuras propias de la experiencia dentro de un determinado universo cultural. En Eliseo Veron (comp). (1974).

\section{Referencias}

Álbum Familiar de Bogotá. (2013). Bogotá: Secretaría Distrital de Recreación y Deporte.

Asencio, P. (coord) (2008). Diseñadores de moda. Barcelona: Monsa Editores.

Baudrillard, J. (2002). Crítica a una economía política del signo. México: Siglo XXI Editores. (2010): El sistema de los objetos. México: Siglo XXI Editores. (1982). El intercambio simbólico y la muerte. Venezuela: Monte Ávila Editores

Benjamin, W. (1971). Iluminaciones I. Madrid: Taurus.

Berman, M. (1988). Todo lo sólido se desvanece en el aire. México: Siglo XXI Editores.

Boucher, F. (2009). Historia del traje en Occidente, desde los orígenes hasta la actualidad. Barcelona: Gustavo Gili.

Berger, P., Luckmann, T. (1968). La construcción social de la realidad. Buenos Aires: Amorrortu

Belting, H. (2007). Antropología de la imagen. Madrid: Conocimiento.

Bourdieu, P. (1994). Distintion, A social critique of the judgement of taste. London:Routledge.

Braudel, F. (1981). La dinámica del capitalismo. México: Fondo de cultura Económica.

Castro-Gómez, S. (2009). Tejidos Oníricos, Movilidad, capitalismo y biopolítica en Bogotá (1910-1930). Bogotá: Pontificia Universidad Javeriana.

Cirlot, E. (2006). Diccionario de Símbolos. Madrid: Ciruela.

De Certeau, M. (2000). La invención de lo cotidiano. México: Universidad Iberoamericana/ITESO/Centro Francés de Estudios Mexicanos y Centroamericanos.

Fundación Misión Colombia. (1989). Historia de Bogotá. Bogotá: siglo XX. Salvat- Villegas.

Freud, S. (1974). Obras completas de Sigmund Freud. Volumen XIII - Tótem y tabú, y otras obras (1913-1914). Buenos Aires \& Madrid: Amorrortu Editores.

Foucault, M. (1978). El orden del discurso. Buenos Aires: Siglo XXI Editores. (1999). Saber y verdad. Madrid: Ediciones la Piqueta.

Jodelet, D. (1987). La representación social: fenómenos, concepto y teoría, en: Londoño, Patricia y Londoño Santiago, Vida diaria en las ciudades colombianas. En Nueva Historia de Colombia. Bogotá: Planeta. 
Mejía, P. (1999). Los años del cambio, Historia Urbana de Bogotá 1820-1910. Bogotá: Centro Editorial Javeriano.

Moscovici, S., Billing, M., Rosenbaum, D., \& Ibáñez, T. (1993). Psicología social, II: Pensamiento y vida social, psicología social y problemas sociales. Barcelona: Paidós Ibérica.

Pedraza, Z. (1999), En cuerpo y alma, visones del progreso y la felicidad. Bogotá: Universidad de los Andes.

Revista Cromos, 1920-1930.

Soto Borda, C. (2008). Diana la cazadora. Bogotá: Panamericana.

Saltzman, A. (2007). El cuerpo diseñado, sobre la forma en el proyecto de la vestimenta. Buenos Aires: Paidós.

Traversa, O. (1997). Cuerpos de papel, figuraciones del cuerpo en la prensa. Barcelona: Gedisa.

Verón, E. (1998). La semiosis social. Barcelona: Gedisa.

Viviescas, F. (compilador). (1998). Colombia: el despertar de la modernidad. Bogotá: Ediciones Foro Nacional por Colombia.

Zecchetto, V. (coordinador). (2005). Seis semiólogos en busca del lector. Buenos Aires: La Crujía. Aires.

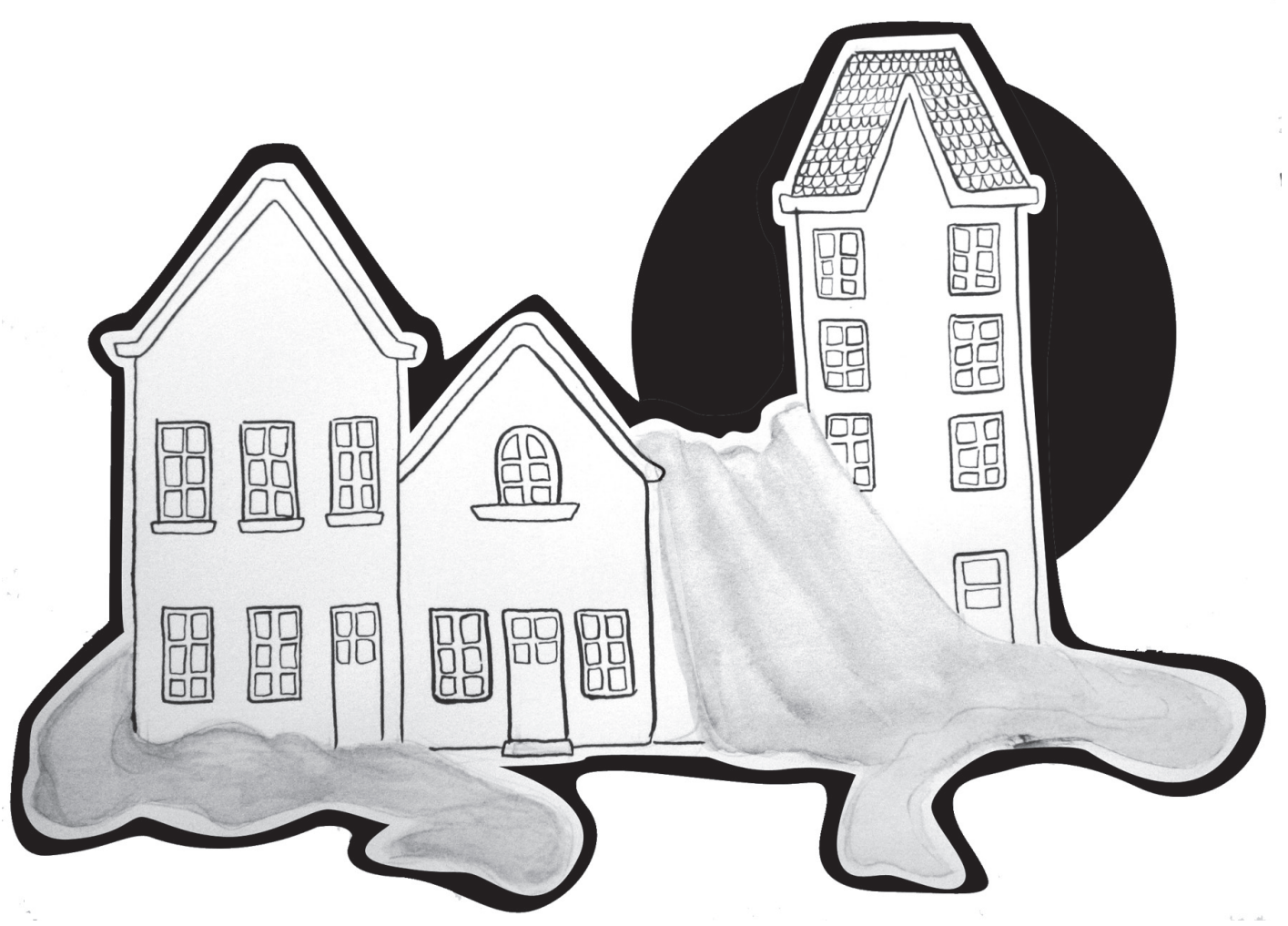

